\title{
The Enforcement Provisions of the Civil Rights Act of 1866: A Legislative History in Light of Runyon v. McCrary
}

\author{
Robert J. Kaczorowski†
}

Surely we have the authority to enact a law as efficient in the interest of freedom, now that freedom prevails throughout the country, as we had in the interest of slavery when it prevailed in a portion of the country. ${ }^{1}$

This brief statement in support of the Civil Rights Act of $1866^{2}$ by its author, Senator Lyman Trumbull, reveals the two most important issues confronting the bill's supporters: whether Congress possessed any authority to protect and enforce civil rights, and what were the most effective means of securing civil rights in light of contemporary legal doctrine and the nature of the civil rights violations that compelled the statute's framers to legislate. Senator Trumbull's reference to the Fugitive Slave Acts of $1793^{3}$ and $1850^{4}$ also suggests one of the bitter ironies of the statute's history, for they served as legislative models of congressional enforcement of a constitutional provision securing a fundamental right of United States citizenship, the property right of slaveholders in their slaves. Moreover, the constitutional provision these statutes were enacted to implement, the fugitive slave clause, ${ }^{5}$ as interpreted by the United States Supreme Court, provided the framers of the Civil Rights Act with a theory of constitutional delegation of plenary congressional authority to secure fundamental rights which they invoked in their efforts to enforce civil rights.

The purpose of this Comment is to examine the history of the enactment and early enforcement of the Givil Rights Act of 1866 from the

\footnotetext{
$\dagger$ Professor of Law, Fordham University. Counsel for amicus curiae of distinguished historians in Patterson v. McLean Credit Union, No 87-107 (U.S. filed July 17, 1987).

I am grateful to the following individuals for their help and suggestions: Robert Byrn, Sabina Hollis, Stanley Katz, William LaPiana, Eben Moglen, William Nelson, Eric Schnapper, Joseph Sweeney, and Georgene Vairo. I am especially grateful to Fordham University School of Law for its generous financial support.

1. Cong. Globe, 39th Cong., 1st Sess. 475 (1866) [hereinafter Cong. Globe] (Sen. Trumbull).

2. Ch. 31,14 Stat. 27 (1866) (codified as amended at 42 U.S.C. $\S \S 1981-1986$ (1982)).

3. Ch. 7, 1 Stat. 302 (1793).

4. Ch. 60,9 Stat. $462(1850)$.

5. U.S. Const. art. IV, $\S 2$.
} 
perspective of the remedies Congress sought to provide to meet the problems that necessitated the legislation. Its main foci are the statute's enforcement provisions and their early implementation, an aspect of the history of the statute that has not been fully considered in relation to section one, the provision that has received the most scholarly attention. ${ }^{6}$ The occasion of this study is the Supreme Court's reconsideration of Runyon v. McCrary ${ }^{7}$ in Patterson v. McLean Credit Union. ${ }^{8}$ The specific question the Court will decide is whether the Civil Rights Act of 1866 provides remedies for private acts of racial discrimination which violate the right to contract secured by section one of the statute. Runyon held that it does. The Court will decide whether to restrict the scope of the Civil Rights Act to discriminatory state action. The basis of the Court's reconsideration appears to be a question of legislative intent: whether the framers intended the statute to protect civil rights from discriminatory state action alone, or from private discrimination as well. This Comment concludes that, if the intent of the legislative framers and the interpretation given the statute by the federal judges and legal officers who were charged with enforcing it on its enactment are dispositive, then Runyon was correctly decided.

This history will show that interpretations of the Civil Rights Act of 1866 as limited to state action are anachronistic and historically incorrect because the framers did not intend, and probably could not have intended, to legislate within a concept of state action. ${ }^{9}$ This conclusion follows from the constitutional and legal doctrines within which the framers legislated in 1866 to enforce civil rights, from the nature of the civil rights violations which confronted them, and from the remedies they provided in the Civil Rights Act of 1866 to enforce civil rights directly in the federal courts. - This Comment will explain the constitutional doctrines of American federalism-known as dual sovereignty-state sovereign immunity, and the general rules of equity relating to injunctions, the remedy Congress would have had in mind if it had intended to protect against discriminatory state action as we understand the doctrine today.

This explanation will show that in 1866 legal doctrine restricted Congress to enforcing rights against private individuals. Congress did not have

6. The most comprehensive and systematic study of civil rights enforcement during reconstruction was published only recently. R. Kaczorowski, The Politics of Judicial InTERPRetarion: The Federal Courts, Department of Justice and Givil Rights, 186601876 (1985).

7. 427 U.S. 160 (1975).

8. 108 S. Ct. 1419 (1988) (ordering reargument).

9. Runyon, 427 U.S. at 192-214 (White, J., dissenting); Jones v. Alfred H. Mayer Co., 392 U.S. 409, 449-80 (1968) (Harlan, J., dissenting). See Kaczorowski, To Begin the Nation Anew: Congress, Citizenship, and Civil Rights After the Civil War, 92 AM. HIST. REv. 45 (1987) [hereinafter To Begin the Nation Anew]; Kaczorowski, Searching for the Intent of the Framers of Fourteenth Amendment, 5 CoNN. L. Rev. 368, 370-71 (1973) [hereinafter Searching for Intent]; Kaczorowski, Revolutionary Constitutionalism in the Era of the Civil War and Reconstruction, 61 N.Y.U. L. Rev. 863, 869 n.19 (1986) [hereinafter Revolutionary Constitutionalism]. 
authority directly to enforce rights against the states. Rather than excluding private individuals, Congress expanded the scope of civil rights by adding state officials within its provisions. Moreover, Congress could enforce only rights secured by the Constitution and laws of the United States, and it could provide for their enforcement only in federal courts. Congress had no authority to compel state officials to enforce federal rights or to perform federal duties. Nor did Congress have authority to enforce rights conferred by the states or to interfere with state enforcement of any rights, whether secured by the Constitution or conferred by the states.

Moreover, Congress could not enforce even federal rights directly against state officials because the officials were immune from civil suit. Even apart from sovereign immunity, the equitable rules relating to the remedy of injunction would have barred its use as a means of restraining state officials from enforcing discriminatory state laws and from the discriminatory administration of impartial laws. Constitutional doctrines and legal rules in 1866 would not have provided the framers with the notion of a state action limitation on Congress' authority to enforce civil rights. Nor would they have suggested to the framers the dichotomy between state action and private action. These doctrines and rules as the framers understood and used them in enacting the Givil Rights Act of 1866 point to one conclusion: that the framers intended to exercise plenary authority to enforce civil rights by conferring jurisdiction on the federal courts to give direct relief to victims of civil rights violations.

\section{The Thirty-Ninth Congress' Understanding of Its Power to ENForce Civil Rights}

The controversial issue that confronted Congress in its efforts to secure civil rights in 1866 was not whether national civil rights enforcement should extend to private individuals or be limited to eliminating discriminatory state laws, but whether Congress had any authority to secure civil rights in any manner at all. Since the states had been the traditional guardians of fundamental rights, Republicans had to find an explicit or an implied constitutional delegation of authority to secure such rights before Congress could legislate to protect and enforce the civil rights of Americans.

Congressional proponents of the Civil Rights Act of 1866 found constitutional authorization to enforce civil rights in the Thirteenth Amendment. The Thirteenth Amendment abolished slavery. As the quotation at the beginning of this Comment indicates, the framers insisted that this Amendment delegated to Congress as much authority to secure the freedom established by its abolition of slavery as Congress previously had possessed to secure the property right of slaveholders in their slaves. The 
framers specifically relied on the United States Supreme Court's interpretation of the constitutional provision that secured the personal property right of slaveholders in their slaves as authority for their view of Congress' plenary power to secure the personal rights of the slaves emancipated by the Thirteenth Amendment. This constitutional provision was the fugitive slave clause:

No person held to Service or Labour in one State under the Laws thereof, escaping into another, shall in Consequence of any Law or Regulation therein, be discharged from such Service or Labour; but shall be delivered up on Claim of the Party to whom such Service or Labour may be due. ${ }^{10}$

The United States Supreme Court declared in 1842 that it should interpret this provision "in such a manner, as, consistently with the words, shall fully and completely effectuate the whole objects of it."11 In an opinion written by Justice Joseph Story, the Court acknowledged that this clause was a negative prohibition on the states, but nonetheless held that this "clause manifestly contemplates the existence of a positive, unqualified right on the part of the owner of the slave, which no state law or regulation can in any way qualify, regulate, control, or restrain."12 The clause also "implies a guaranty -and a duty," namely, a duty to permit slaveowners to use the courts as a guaranty of the property right. ${ }^{13}$ Story concluded that, "If, indeed, the Constitution guarantees the right, and if it requires the delivery upon the claim of the owner (as cannot well be doubted), the natural inference certainly is, that the national government is clothed with the appropriate authority and functions to enforce it."14

Story then wrote a passage that was quoted in Congress by the Chairman and a member of the House Judiciary Committee in support of Congress' authority to enact the Civil Rights Act of 1866. In this passage Justice Story laid down several principles of constitutional interpretation: that the constitutional recognition of a right delegated to Congress plenary authority to enforce it; that the states could not be compelled to enforce the constitutional right; and that the constitutional recognition of the right imposed on the national government the sole duty and conferred plenary authority to enforce it:

The fundamental principle, applicable to all cases of this sort, would seem to be, that where the end is required, the means are given; and where the duty is enjoined, the ability to perform it is contemplated

10. U.S. Const. art. IV, $\S 2$, cl. 3 .

11. Prigg v. Pennsylvania, 41 U.S. (16 Pet.) 539, 612 (1842).

12. Id.

13. Id. at 614

14. Id. at 615. 
to exist on the part of the functionaries to whom it is entrusted. The clause is found in the national Constitution, and not in that of any state. It does not point out any state functionaries, or any state action to carry its provisions into effect. The states cannot, therefore, be compelled to enforce them; and it might well be deemed an unconstitutional exercise of the power of interpretation, to insist that the states are bound to provide means to carry into effect the duties of the national government, nowhere delegated or intrusted to them by the Constitution. On the contrary, the natural, if not the necessary conclusion is, that the national government, in the absence of all positive provisions to the contrary, is bound, through its own proper departments, legislative, judicial, or executive, as the case may require, to carry into effect all the rights and duties imposed upon it by the Constitution. ${ }^{15}$

The concurring and dissenting opinions of Chief Justice Taney and Justices Thompson, Wayne, Daniel, and McLean all affirmed the holding that the constitutional prohibition against state interference with the rendering up of fugitive slaves recognized and secured an affirmative property right of the slaveholder in his slaves, and that this delegated to Congress plenary if not exclusive authority to protect and enforce the property right directly and independently of the states against private individuals; notwithstanding state laws to the contrary. ${ }^{16}$ The Court consistently affirmed its interpretation of this constitutional provision. ${ }^{17}$

The framers' theory of the Thirteenth Amendment was much broader than the "badges of slavery" concept expressed by the United States Supreme Court in $1968 .{ }^{18}$ Since they understood the original Constitution to delegate to Congress plenary authority to enforce the master's absolute personal right of property in his slave, the framers interpreted the Thirteenth Amendment as a delegation of plenary authority to enforce the freedmen's absolute rights as free men. Imbued with the Hamiltonian conception of constitutional interpretation that was expressed by the Supreme Court under Chief Justices John Marshall and Roger Taney in cases such as McCulloch $v$. Maryland and Prigg v. Pennsylvania, ${ }^{19}$ the framers, relying on those cases, ${ }^{20}$ interpreted the Thirteenth Amendment's

15. Id. at 615-16 (quoted in Cong. Grobe, supra note 1, at 1294 (Rep. Wilson); id. at 1836 (Rep. Lawrence)).

16. Prigg v. Pennsylvania, 41 U.S. at 626-33 (Taney, C.J., concurring and dissenting); id. at 634 (Thompson, J., concurring); id. at 636, 638, 643, 645-47 (Wayne, J., concurring), id. at 651 (Daniel, $\mathrm{J}$, concurring and dissenting); id. at 661 (McLean, J., concurring and dissenting).

17. Dred Scott v. Sandford, 60 U.S. (19 How.) 393, 451-52 (1856); Moore v. Illinois, 55 U.S. (14 How.) 13, 17-19 (1852); Jones v. Van Zandt, 46 U.S. (5 How.) 215, 225, 229-30 (1847); see also Miller v. McQuerry, 17 F. Cas. 335, 338-39 (C.C.D. Ohio 1853) (No. 9,583).

18. Jones v. Alfred H. Mayer Co., 392 U.S. 409, 439 (1968).

19. McCulloch v. Maryland, 17 U.S. (4 Wheat.) 316 (1819); Prigg v. Pennsylvania, 41 U.S. (16 Pet.) 539 (1842).

20. See, e.g., Cong. Globe, supra note 1, at 1118, 1294 (Rep. Wilson); id. at 1836 (Rep. Williams). 
negative prohibition of slavery as an affirmative guarantee of liberty to all Americans. Thus, when Senator Lyman Trumbull introduced his Civil Rights Bill to the Senate, he explained that in abolishing slavery, the Thirteenth Amendment "declared that all persons in the United States should be free. This measure is intended to give effect to that declaration and secure to all persons within the United States practical freedom."21 Trumbull and other Republicans in both Houses of Congress interpreted the liberty guaranteed by the Thirteenth Amendment as the status and fundamental rights of freemen, the rights to life, liberty, and property and all the rights that follow from these. ${ }^{22}$ They equated this status and these rights with the status and rights of United States citizenship. ${ }^{23}$ Although Republicans believed that an exact enumeration of the specific rights incident to the generic rights to life, liberty, and property was impossible, ${ }^{24}$ they did enumerate some of these specific rights in section one of the Civil Rights Act of 1866 . The rights they specified mirrored the civil rights deprivations they were trying to remedy: the economic rights to contract and to property, the means necessary to enforce these rights in the courts, and the right to governmental protection of persons and property. The enumeration of these rights was not only a direct response to conditions in the South, it was also an expression of the framers' understanding of the rights essential to political and economic freedom and individual autonomy. Because the framers believed that the Constitution and, with the passage of the Civil Rights Act, the laws of the United States secured to Americans the status and fundamental rights of free men as the status and rights of United States citizenship, the framers understood United States citizenship to be primary and state citizenship to be subordinate to and derivative of United States citizenship. ${ }^{25}$

- The consequences of this constitutional theory on American federalism were revolutionary. ${ }^{26}$ The framers were claiming that Congress possessed

21. Id. at 474 (Sen. Trumbull).

22. See, e.g., id. at 1780-81 (Sen. Trumbull); id. at 503-04 (Sen. Howard); id. at 570 (Sen. Morrill); id. at 602, 741 (Sen. Lane); id. at 1255 (Sen. Wilson); id. at app. 101 (Sen. Yates); id. at 1118 (Rep. Wilson); id. at 1124 (Rep. Cook); id. at 1151-52 (Rep. Thayer); id. at 1833 (Rep. Lawrence). For additional authority in and out of Congress, see Kaczorowski, Revalutionary Constitutionalism, supra note 9 , at 898-99 n.156.

23. See sources cited supra note 22 .

24. Cong. GloBE, supra note 1, at 1293 (Rep. Shellabarger). Indeed, Congressman Bingham understood the Civil Rights Bill as a guarantee of the Bill of Rights. It is because the Supreme Court had interpreted the Bill of Rights as restrictions on the power of the national government and not as delegations of authority that Bingham believed that a constitutional amendment delegating this authority to Congress was necessary before Congress constitutionally could enact a law such as the Civil Rights Act. Id. at 1291. His stated purpose in drafting and proposing the resolution that became the Fourteenth Amendment was to arm Congress with the authority to enforce the Bill of Rights. Id. at $1033,1088-94,1291$.

25. Id. at 1756 (Sen. Trumbull). Some of the supporters expressed the belief that the due process clause of the Fifth Amendment of the Constitution also authorized Congress to secure the fundamental rights to life, liberty, and property. Id. at 1152 (Rep. Thayer); id. at 1294 (Rep. Wilson); id. at 1833 (Rep. Lawrence).

26. Kaczorowski, Revolutionary Constitutionalism, supra note 9, at 916; Kaczorowski, To Begin 
plenary authority to secure the civil rights of all Americans as rights of United States citizenship. They freely asserted their intention to enforce the rights of white and black Americans. ${ }^{27}$ They distinguished these rights from state-conferred rights with which they insisted they had no intention of interfering because, under the doctrine of dual sovereignty in 1866, these rights were within the exclusive jurisdiction of the states. The framers identified as state-conferred rights such privileges as the right to attend public schools, to public accommodations, to transportation, to marry, to vote in state and local elections, and to hold state and local offices. ${ }^{28}$ Consequently, when the framers denied that the Civil Rights Act would interfere with these rights, it was precisely because they regarded these rights as state-enforced rights of state citizenship beyond Congress' legislative authority. ${ }^{2 \theta}$ The framers' theory of citizenship and civil rights, therefore, was inconsistent with the doctrine of state action since state action assumes that the framers intended only to secure an equality in stateconferred rights. The Democratic opposition understood the revolutionary consequences of the Republican theory of citizenship and congressional civil rights enforcement authority under the Thirteenth Amendment and warned that "The principles involved in this bill, if they are legitimate and constitutional, would authorize Congress to pass civil and criminal codes for every State of the Union." 30 The constitutional doctrine "would wholly absorb all reserved State sovereignty and rights."31 If the status and fundamental rights of freemen were secured to Americans by the Constitution and laws of the United States through United States citizenship, as congressional Republicans insisted, then Congress did indeed possess plenary and therefore potentially exclusive authority over civil rights and could supplant legislatively state civil and criminal codes.

The framers of the Givil Rights Act expressly intended to exercise plenary authority and to displace state law to the extent necessary to enforce the absolute rights of all Americans, not merely to provide equal rights under state law. Section one of the Givil Rights Act supplanted state law in three important respects. First, it conferred citizenship on all persons

the Nation Anew, supra note 9, at 54.

27. Cong. Globe, supra note 1, at 474, 599 (Sen. Trumbull); id. at 1118 (Rep. Wilson). For additional authority, see Kaczorowski, Revolutionary Constitutionalism, supra note 9, at 897 n.153.

28. Kaczorowski, Revolutionary Constitutionalism, supra note 9, at 926.

29. See, e.g., Cong. Globe, supra note 1, at 599-600 (Sen. Trumbull); id. at 1294 (Rep. Wilson). Nonetheless, opponents warned that the statute could be applied as requiring equality even in these state-conferred rights by expansive interpretations of the rights to contract and property, and by virtue of its equal protection provision. See id. at 505 (Sen. Johnson); id. at 606 (Sen. Saulsbury); id. at 1121 (Rep. Rogers); id. at 1291 (Rep. Bingham). The framers amended the original version of section one to eliminate a declaration that there shall be no discrimination in civil rights generally "to quiet the alarm of the opposite party" that it might confer the right to vote, a right the framers claimed had been delegated by the Constitution to state jurisdiction. Id. at 1263 (Rep. Broomall).

30. Id. at 1414 (Sen. Davis). For additional authority, see Kaczorowski, Revolutionary Constitutionalism, supra note 9 , at 903-06.

31. Cong. Globe, supra note 1 , at app. 185 (Sen. Davis). 
born or naturalized in the United States and not subject to any foreign power, except for Indians not taxed. In conferring citizenship Congress precluded the states from denying citizenship to qualified persons.

Second, it conferred upon all United States citizens the absolute rights specified. Thus, Senator Trumbull declared:

To be a citizen of the United States carries with it some rights; and what are they? They are those inherent, fundamental rights which belong to free citizens or free men in all countries, such as the rights enumerated in this bill, and they belong to them in all the States of the Union. ${ }^{32}$

In other words, the citizen possessed these rights independent of state law. Senator Trumbull insisted "that the federal government has authority to make every inhabitant of Pennsylvania a citizen, and clothe him with the authority to inherit and buy real estate, and the State of Pennsylvania cannot help it."33 Congressman William Lawrence, a member of the House Judiciary Committee which was responsible for the civil rights bill in the House of Representatives, explained section one in the same way:

There are certain absolute rights which pertain to every citizen, which are inherent, and of which a State cannot constitutionally deprive him. But not only are those rights inherent and indestructible, but the means whereby they may be possessed and enjoyed are equally so. . . . Every citizen, therefore, has the absolute right to live, the right of personal security, personal liberty, and the right to acquire and enjoy property. These are rights of citizenship. As necessary incidents of these rights there are others, as the right to make and enforce contracts, to purchase, hold, and enjoy property, and to share the benefit of laws for the security of person and property. ${ }^{34}$

The Civil Rights Act of 1866 conferred these absolute rights of citizenship, and all citizens possessed these rights, in the words of section one, "any [state] law, statute, ordinance, regulation, custom, to the contrary notwithstanding."

Third, in guaranteeing that all United States citizens would enjoy the enumerated rights and immunities as white citizens enjoyed them, section one prohibited the states from discriminating on the basis of race in regulating the exercise of these rights. Although the states could no longer deprive citizens of these rights, the framers intended that the states retain

\footnotetext{
32. Id. at 1757 (Sen. Trumbull) (emphasis added).

33. Id. at 500 .

34. Id. at 1833 (Rep. Lawrence); see also id. at 478 (Sen. Saulsbury); id at 1413 (Sens. Van Winkle and Trumbull); id. at 1759 (Sen. Trumbull); id. at 1118 (Rep. Wilson); id. at App. 157 (Reps. Delano and Wilson); id. at 1832, 1836, 1837 (Rep. Lawrence); id. at 1679, 1680 (Pres. Johnson's veto message).
} 
their authority to regulate the exercise and enjoyment of civil rights. ${ }^{35}$ Section one therefore conferred citizenship and some of the rights of United States citizenship in a way that permitted the states concurrent authority to regulate impartially the exercise of these rights.

If the Civil Rights Act had made a blanket grant of the specified rights to all citizens, the grant would have voided state laws regulating the manner in which they were enjoyed and exercised. State regulations based on sex, marital status, age, and mental disability, which the framers and legal authorities on which they relied considered reasonable and legitimate discriminations, would have been abolished if the Civil Rights Act had conferred the right unconditionally. ${ }^{38}$ The framers wanted to avoid this result. ${ }^{37}$ They succeeded by providing that all citizens shall have the same enumerated rights "as [are] enjoyed by white citizens." the framers of the Civil Rights Act intended to preserve concurrent state jurisdiction over civil rights.

\section{The Thirty-Ninth Congress' Understanding of the LIMITS ON ITS POWERS}

The framers' scheme of concurrent jurisdiction over civil rights has been misinterpreted. Scholars and jurists have incorrectly read into the

35. Kaczorowski, To Begin the Nation Anew, supra note 9, at 56.

36. See, e.g., Cong. Globe, supra note 1, at 1835-36 (Rep. Lawrence).

37. Id. at 505 (Sens. Johnson, Trumbull, and Fessenden); id. at 572, 574 (Sen. Henderson); id. at 573-74 (Sen. Williams); id. at app. 158-59 (Reps. Delano, Wilson, and Niblack); id. at 1832 (Rep. Lawrence).

38. As a New York Evening Post editorial noted:

Congress does not say in this bill by what rules evidence shall be given in courts, by what tenure property shall be held, or how a citizen shall be protected in his occupation. It only says to the states, whatever laws you pass in regard to these matters, make them general; make them for the benefit of one race as well as another.

N.Y. Evening Post (n.d.) (collected in Scrapbook on the Civil Rights Bill 32 (E. McPherson ed., n.d.) in Edward McPherson Papers (collection available in Library of Congress)). The original version of section one did not contain the words "as is enjoyed by white citizens." It simply stated that inhabitants of the states shall have the same enumerated rights. This clearly was a grant of absolute rights. The House amended the bill by changing inhabitants of the states to "citizens of the United States," and by adding the clause referring to white citizens. CONG. GLOBE, supra note 1, at 1115 (Rep. Wilson). Wilson explained that the change to United States citizens was intended to confine the operation of the bill "to citizens of the United States, instead of extending it to the inhabitants of the several states, for there seems to be some doubt concerning the power of Congress to extend this protection to such inhabitants as are not citizens." The other words were added without a single comment. Moreover, Senator Trumbull reported that he and the members of the Senate Judiciary Committee regarded the addition of "as is enjoyed by white citizens" as "superiluous." Indeed, he said:

I do not think they alter the bill. I think the bill would be better without them, but they have been adopted by the House of Representatives. We did not think they altered the meaning of the bill; and we did not think it worth-while to send the bill back just because those words were inserted by the House.

Id. at 1413. Justice White interprets this language in 42 U.S.C. $\S 1981$ as "clearly refer[ring] to rights existing apart from this statute." Runyon v. McCrary, 427 U.S. 160, 193-94 (1975). If one assumes that $\$ 1981$ is equivalent to section one of the Civil Rights Act of 1866 , the framers' understanding clearly contradicts Justice White's interpretation. 
Civil Rights Act a state action interpretation. ${ }^{38}$ Nineteenth century doctrines of constitutional law and American federalism strongly suggest that it is anachronistic to interpret the statute and the debates leading to its enactment in terms of our understanding of the doctrine of state action. The framers would not have understood the dichotomy between state action and private action as a limitation on Congress' authority to enforce civil rights as we understand this dichotomy today.

The fugitive slave clause cases are again important because they provided the framers with their understanding of the scope of Congress' authority to provide remedies for the violation of constitutionally secured rights. Prigg had held that Congress could compel enforcement of the constitutionally-guaranteed property right of slaveholders only through the federal courts and only by federal officials. Some question exists whether the majority held that the states were excluded from enforcing this right. ${ }^{10}$ The better view appears to be that a majority did not agree with Story that the authority to enforce that right was exclusively Congress. ${ }^{21}$ In any case, the Court later permitted the states, indirectly and voluntarily, to assist slave owners in enforcing their constitutionally-secured property right through the exercise of their police powers. ${ }^{22}$ Nonetheless, it reaffirmed on the eve of the Civil War the Court's holding in Prigg "that the Federal Government, under the Constitution, has no power to impose on a State officer, as such, any duty whatever, and compel him to perform it." ${ }^{\text {"33 }}$ Consequently, Congress' power to enforce and protect constitutionally-secured rights did not include the power to compel or to prohibit state action in regard to such rights. This constitutional doctrine of congressional authority to secure constitutional rights is just the opposite of the theory of congressional authority to enforce civil rights under the doctrine of state action.

This doctrine of congressional remedial authority was the product of mid-nineteenth century theories of federalism, including dual sovereignty, sovereign immunity and separation of powers. The Supreme Court explained dual sovereignty in 1858 as a federal system in which the national and state governments were distinct sovereignties that acted independently of one another:

39. See Runyon, 427 U.S. at 192-214 (White, J., dissenting); Jones v. Alfred H. Mayer Co., 392 U.S. at 449-76 (Harlan, J., dissenting); 7 C. Fatrman, History of the Supreme Court of the United States, Reconstruction and Reunion, 1864-88 Part One 1117-1300 (1971); see also Kaczorowski, Revolutionary Constitutionalism, supra note 9, at 69 n.19; Kaczorowski, Searching for Intent, supra note 9.

40. See R. Newmeyer, Supreme Court Justice Joseph Story $372-78$ (1985).

41. Id. at $374-75$.

42. Moore v. Illinois, 55 U.S. (14 How.) 13, 17-18 (1852). The court recognized concurrent state authority in another area exclusively delegated to Congress-the interstate commerce power. See Cooley v. Board of Wardens, 53 U.S. (12 How.) 299 (1851).

43. Kentucky v. Dennison, 64 U.S. (23 How.) 67, 108 (1860). 
[T] he powers of the General Government, and of the State, although both exist and are exercised within the same territorial limits, are yet separate and distinct sovereignties, acting separately and independently of each other, within their respective spheres. ${ }^{44}$

This notion remained strong through the nineteenth century. The Supreme Court emphasized "the distinct and independent character of the two governments" in 1871:

In their laws, and mode of enforcement, neither is responsible to the other. How their respective laws shall be enacted; how they shall be carried into execution; and in what tribunals, or by what officers; and how much discretion, or whatever any at all shall be vested in their officers, are matters subject to their own control, and in the regulation of which neither can interfere with the other. ${ }^{45}$

Not only did this mean that Congress could not legislate directly to compel or restrain state action, but also that the courts of one sovereignty were "far beyond the reach of the other." 46

The doctrine of sovereign immunity reinforced the concept of national and state governments as independent sovereignties. The general rule of sovereign immunity in the nineteenth century was that a state could not be sued unless it consented to be sued. ${ }^{47}$ This immunity protected state officers when they were sued in their official capacity for acts committed under lawful authority. ${ }^{48}$ However, state immunity did not protect state officers from suit if the act for which they were being sued was unlawful or was pursuant to an unconstitutional statute ${ }^{49}$ and was ministerial in nature..$^{50}$ In such cases the act of the state officer was not the act of the state because the state could not act unlawfully. Consequently, state officers could only be sued in their capacity as private individuals..$^{\mathbf{3 1}}$

These rules of sovereign immunity were not a matter of federal comity alone. Immunity from civil suit largely stemmed from the principle of the separation of powers. ${ }^{52}$ Although the actions of the legislative and execu-

\footnotetext{
44. Ableman v. Booth, 62 U.S. (21 How.) 506, 516 (1858).

45. Tarble's Case, 80 U.S. (13 Wall.) 397, 407-08 (1871).

46. Riggs v. Johnson, 73 U.S. (6 Wall.) 166, 195-96 (1867).

47. Osborn v. United States, 22 U.S. ( 9 Wheat.) 738, 839 (1824).

48. Governor of Georgia v. Madrazo, 26 U.S. (1 Pet.) 110, 123-24 (1828).

49. Osborn, 22 U.S. at 868; Astrom v. Hammond, 2 F. Cas. 71, 72 (C.C.D. Mich. 1842) (No. 596).

50. Gaines v. Thompson, 74 U.S. (7 Wall.) 347, 352 (1868); Mississippi v. Johnson, 71 U.S. (4 Wall.) 475, 489-90, 498-99 (1866); Board of Comm'rs v. Aspinwall, 65 U.S. (24 How.) 376, 385 (1860); Kendall v. United States, 37 U.S. (12 Pet.) 524, 610 (1838); Astrom, 2 F. Cas. at 73.

51. Ex parte Young, 209 U.S. 123, 159-60 (1907); Fitts v. McGhee, 172 U.S. 516, 526-27 (1898); Hans v. Louisiana, 134 U.S. 1, 16 (1889); Madrazo, 26 U.S. at 123-24; Osborn, 22 U.S. at 868; T. Cooley, The General. Principles of Constitutional law in the United States of AMERICA 118-19 (1880).

52. Louisiana v. Jumel, 107 U.S. 711, 727-28 (1882); Gaines, 74 U.S. at 352; Secretary v. McGarrahan, 72 U.S. (9 Wall.) 298, 312 (1869); Johnson, 71 U.S. (4 Wall.) 498-99; Kendall, 37 U.S.
} 
tive branches of government were "in proper cases" subject to review by the courts, neither branch could be compelled or "restrained in its action by the judicial department." lying this rule in explaining the limited scope of the equitable remedies of mandamus and injunction in suits against public officials:

An officer to whom public duties are confided by law, is not subject to the control of the courts in the exercise of the judgment and discretion which the law reposes on him as a part of his official functions. Certain powers and duties are confided to those officers, and to them alone, and however the courts may, in ascertaining the rights of the parties in suits properly before them, pass upon the legality of their acts, after the matter has once passed beyond their control, there exists no power in the courts, by any of its processes, to act upon the officer so as to interfere with the exercise of that judgment while the matter is properly before him for action. The reason for this is, that the law reposes this discretion in him for that occasion, and not in the courts. ${ }^{54}$

Although the case in which this rule was explained involved the power of the federal courts to compel or restrain the actions of federal executive officers, the same principles applied to state governmental officers. One difference, however, was that a federal court could issue the writ of mandamus to a state officer only to execute a prior judgment of the court and only to compel a ministerial act by the performance of which alone the plaintiff's remedy could be effectuated. ${ }^{5 s}$ Since the enforcement of most statutes required an exercise of discretion, rules of sovereign immunity made injunctive relief unavailable in 1866 as a federal remedy for the victims of civil rights violations committed by state officers.

Moreover, the general rules of equity virtually eliminated the injunction as a device to prohibit state officers from violating civil rights, whether by enforcing discriminatory statutes or by administering state law in a racially or politically discriminatory manner. As an equitable remedy, the injunction was available only if there was no adequate remedy at law. ${ }^{58}$ In the nineteenth century, final review by the United States Supreme Court, as provided for by Congress in section 25 of the Judiciary Act of 1789 , was regarded as the normal and adequate remedy to enforce

at $610-11$.

53. Johnson, 71 U.S. at $499-500$.

54. Gaines, 74 U.S. at 352; accord Astrom, 2 F. Cas. at 73.

55. McIntire v. Wood, 11 U.S. (7 Cranch) 505 (1813); Kendall, 37 U.S. at 616-17; McGarrahan, 76 U.S. at 311-12; Board of Comm'rs, 65 U.S. at 385; Riggs v. Johnson County, 73 U.S. (6 Wall.) 166, 188-89, 197-98 (1867).

56. W. KerR, a Treatise on the Law and Practice of Injunctions in Equity 3, 19 (1871). The long-standing requirement that there be no adequate remedy at law before an injunction will issue reflects the extraordinary nature of the equitable remedy. 
constitutional rights. ${ }^{87}$ Consequently, injunctive relief would not have been available to enforce civil rights against state action, because claimants would not have been able to satisfy the "inadequate remedy at law" requirement. Moreover, the injunction in the nineteenth century was a remedy restricted to the protection of property rights and rights of a pecuniary nature; it was not available to protect other personal and civil rights. ${ }^{38}$ In light of these rules, the framers would not have thought injunctions to restrain state officers from violating civil rights a suitable remedy.

Indeed, noticeably absent from the remedies Congress incorporated into the Civil Rights Act is injunctive relief, the remedy one would have expected to find had the framers intended merely to remove legal disabilities under a state action conception of federal civil rights law. The framers, bound by stricter rules of federalism, sovereign immunity and equity than those of today, would not have thought to provide injunctive relief against the enforcement of discriminatory state action as a remedy for the enforcement of civil rights. Moreover, most civil litigation was suits between private parties. Consequently, a party whose civil rights were infringed by individuals or corporations acting under color of law would sue the individual or corporation, not the state. ${ }^{58}$ It is not surprising, therefore, that suits against state officers for injunctive relief were rare until the end of the nineteenth century. Legal treatises written on injunctions and the law of equity as late as the 1880's gave such actions only cursory attention, usually in a paragraph with citations to only a few decisions. ${ }^{60}$ The rules regarding civil actions against state officials were imprecisely reported, reflecting the treatise writers' lack of familiarity with the subject and its relative unimportance to them. It was nor until the 1890 's that treatises gave more than passing attention to the subject. ${ }^{81}$

57. The Supreme Court held that Congress, in section 25 of the Judiciary Act of 1789 , provided for tinal review in the Supreme Court as the normal and adequate remedy for a violation of constitutional rights. Civil Rights Cases, 109 U.S. 3, 12 (1883). See also Neal v. Delaware, 103 U.S. 370, 387 (1880); Virginia v. Rives, 100 U.S. 313, 321-22 (1879).

58. Gee v. Pritchard, 2 Swans. 402, 418, 36 Eng. Rep. 670, 675 (Ch. 1818); In re Sawyer, 124 U.S. 200, 210 (1887); In re Debs, 158 U.S. 564, 593 (1895); Chappell v. Stewart, 82 Md. 323, 325, 33 A. 542, 543 (1896); Roberson v. Rochester Folding Box Co., 171 N.Y. 538, 552-53, 64 N.E. 442, 446 (1902); Everett v. Harron, 380 Pa. 123, 130-32, 110 A.2d 383, 387-88 (1955); W. KeRR, supra note 56, at 1; T. Cooley, supra note 51, at 119; 2 C. BeACH, JR., Commentaries on the Law of INJUNCTIONS 1402 (1895); W. DEFunIAK, HANDBOOK OF MODERN EQUTTY 130 (2d ed. 1956).

59. See, e.g., In re Turner, 24 F. Cas. 337 (C.C.D. Md. 1867) (No. 14,247) (suit by apprentice against master seeking release from apprenticeship contract that violated her right to equal protection); Slaughter-House Cases, 83 U.S. (16 Wall.) 36 (1872) (suit by butchers agitinst state chartered corporation); United States v. Buntin, 10 F. 730, 733 (C.C.S.D. Ohio 1882) (civil suit and prosecution of public school teacher for excluding black child from public school); T. Cooley, supra note 51, at 118 (although state may not be sued, corporation chartered by state may be sued even when state is primary stockholder).

60. W. KerR, supra note 56, at 3,599-600; 1 AbBott's United States Practice 222-23 (1871); J. STORY, CoMMENTARIES ON EQUITY JURISPRUdenCE 163 (6th ed. 1873); id. at 180 n.4, 260 (13th ed. 1886); T. COOLEY, supra note 51, at 118-19.

61. 2 C. BEACH, JR., supra note 58, at 1402-18; 2 S. High, A Treatise on the LAW of INJUNCTIONS 1321-45 (1905). 
No one in the debates suggested that an injunction was the proper remedy to enforce the rights Congress was attempting to secure. That the framers did not even consider injunctive relief evinces their understanding that this writ could not issue from a federal court to enjoin state officials from violating civil rights. Because established rules of constitutional law prohibited Congress from compelling state officials to perform federal duties, such as enforcing rights secured by the Constitution and laws of the United States, the framers would have understood that, had they attempted to confer a right to equality in state-conferred rights, citizens would not have been able to enforce this right directly in federal courts. The only remedy Congress could have authorized was the indirect remedy of appeal to the United States Supreme Court. ${ }^{62}$ Furthermore, there was no general federal question jurisdiction in the federal courts until 1875. Therefore, individuals would not have been able to bring a civil action in federal court to void discriminatory state statutes or to enjoin their enforcement unless Congress expressly conferred the right to do so. Congress did not confer this remedy. Individuals thus would have been powerless to enforce their section one rights directly in the federal courts had the Civil Rights Act merely conferred a right to nondiscriminatory state laws and legal process.

Moreover, had Congress intended merely to remove legal disabilities in state law one would expect the statute to have said so clearly, which it does not. ${ }^{63}$ Indeed, had the statute merely conferred a right to equal rights under state law, the only remedy available in 1866 for its violation would

62. Civil Rights Cases, 109 U.S. 3, 12 (1883); Carter v. Greenhow, 114 U.S. 317, 322 (1882); Neal v. Delaware, 103 U.S. 370, 387 (1880). See also cases cited infra note 113.

63. The Fourteenth Amendment expressly prohibits states from infringing the privileges and immunities of United States citizens and from denying to all persons due process and equal protection of the law. U.S. ConsT. amend. XIV, $\S 1$. The proposed amendment was adopted by the same Congress that enacted the Civil Rights Act. However, the prohibitory language of the amendment was not reported to Congress until April 30,1866, well after Congress had adopted the statute on March 15 and then enacted it over the President's veto on April 9, 1866. B. Kendrick, The Journal of the Joint Committee of Fifteen on Reconstruction 303 (1914). Indeed, the Joint Committec did not even consider such language until April 16. Id. at 294-97. This suggests that Congress was not thinking exclusively in terms of state action when it framed and adopted the Civil Rights Act of 1866. Congress adopted the prohibitory language of the Fourteenth Amendment to make it self-executing. See Kaczorowski, Revolutionary Constitutionalism, supra note 9, at 914 . The amendment is selfexecuting in the sense that a party could raise the constitutional claim in a state court, which would be required to bring state law into conformity with the amendment. However, the framers' understanding of constitutional prohibitions against state infringements of fundamental rights was derived from Prigg v. Pennsylvania which held that such prohibitions against the states constituted an affirmative recognition of absolute rights which delegated to Congress plenary authority to enforce them. Therefore, constitutional doctrine as the framers understood it suggests that state action interpretations of the fourteenth amendment are incorrect. Legislation adopted by Congress in 1870 and 1871 to enforce the fourteenth amendment and the history of civil rights enforcement by the Department of Justice in the federal courts from 1866 to 1873 show that the Thirteenth and Fourteenth Amendments were uniformly interpreted by the three branches of the national government as conferring plenary authority on the government to enforce civil rights. It was not until the Supreme Court's interpretation of these amendments in 1873 that they were more narrowly interpreted in a federal court. See R. KACzoRowski, supra note 6; Kaczorowski, Revolutionary Constitutionalism, supra note 9; Kaczorowski, To Begin the Nation Anew, supra note 9. 
have been appeal to the United States Supreme Court from the highest court of the state. ${ }^{84}$ Yet, the framers rejected the insistence of opponents that a writ of error or certiorari was the proper remedy for the violation of the constitutional rights they intended to secure. ${ }^{65}$

The framers of the Civil Rights Act of 1866 legislated within these rules of equity, of constitutional construction, and of sovereign immunity. These rules indicate that the framers did not think in terms of a state action limitation on Congress' authority as we understand this constitutional doctrine. It is hence anachronistic to interpret the Civil Rights Act in terms of our understanding of the doctrine of state action. Constitutional doctrines in 1866 make it unlikely that the framers would have understood congressionally-enforceable civil rights as a right to equality in state-conferred rights. Indeed, the doctrines would have led the framers to believe that Congress was prohibited from legislating directly to compel state and local officers to enforce, or to refrain from violating, rights secured by the Constitution. The only certain federal remedy for the violation of a right secured by the Constitution by a state officer's enforcement of an unconstitutional statute was the indirect and inefficient remedy provided in section 25 of the Judiciary Act of 1789, appeal to the United States Supreme Court. The framers expressed their intention to provide more effective remedies by conferring on the federal courts jurisdiction to administer relief directly rather than by leaving citizens to vindicate their rights in state courts with final appeal to the United States Supreme Court. ${ }^{\text {B8 }}$

\section{The Remedies Provided by the Givil Rights Act of 1866}

I have written elsewhere about the Southern conditions that gave rise to the need for congressional civil rights enforcement. ${ }^{67}$ Congress was well aware of the need to remedy both those conditions that we would today regard as state action and those that we would today regard as private aciton. ${ }^{68}$ In his piece in this issue, Mr. Sullivan details some of these conditions. $^{89}$

Moreover, the framers also were aware of this need, and intended to

64. Cong. Globe, supra note 1, at 500, 604 (Sen. Cowan).

65. Id. at 603 (Sen. Cowan); id. at 605, 606 (Sen. Trumbull); id. at 606 (Sen. Howard); id. at 1151 (Rep. Thornton).

66. Id. at 601 (Sen. Hendricks); id. at 1117-18 (Rep. Wilson); id. at 112ะ (Rep. Cook); id. at 1153 (Rep. Thayer); id. at 1154 (Reps. Eldridge and Thayer); id. at 1263 (Rep. Broomall); id. at 1266-67 (Rep. Raymond); id. at 1271 (Rep. Kerr); id. at 1759 (Sen. Trumbull); id. at app. 158-59 (Rep. Delano).

67. Kaczorowski, Revolutionary Constitutionalism, supra note 9.

68. See Report of THE Joint Comm. on Reconstruction, 39th Cong., 1st Sess. (1866); Report of Carl Schurz on the States of South Carolina, Georgia, Alabama, Mississippi, and Louisiana, S. Exec. Doc. No. 2, 39th Cong., 1st Sess. (1866).

69. Sullivan, Historical Reconstruction, Reconstruction History, and the Proper Scope of Section 1987, 98 YALE L.J. 541 (1989). 
protect white union loyalists and federal officers in the South. ${ }^{70}$ The abrogation of racially discriminatory statutes would not have afforded the protections needed by the freedmen and white unionists from violence perpetrated against them with impunity as local law enforcement officers refused to prosecute offenders. Nor would this have secured emancipation as a practical reality by establishing the North's economic system of free enterprise and free labor based on individual rights, particularly the economic rights of contract and property. The primary need of Southern blacks and white Unionists and federal officers was a federal system of civil and criminal justice to protect them from civil rights violations regardless of the source.

The most difficult practical problem confronting the framers was how to secure civil rights in the South. The military's response to these conditions in 1865 and 1866 suggested to Congress the kinds of remedies the situation demanded. Military commanders viewed the behavior of individual Southerners illicitly legitimated by state and local authority as an abuse of law and legal process. They issued orders to subordinates to protect the freedmen and white Unionists from such oppression. ${ }^{71}$ The commanders in each state nullified the Black Codes in 1865 and 1866 and ordered officers to disregard them. ${ }^{72}$ The military also suspended civil suits and criminal prosecutions brought against unpopular whites and blacks in state courts, and they interposed military authority "to protect them from any penalties or damages that may have been or may be pronounced or adjudged in said [state] courts in any of such cases." obvious attempt to void vagrancy statutes, as well as criminal rape statutes that imposed different penalties for blacks and whites on the same offense, military officers were ordered to protect the freedmen "from prosecutions in any of said States charged with offences for which white persons are not prosecuted or punished in the same manner and degree." ${ }^{\text {" }}$ Military and Freedmen's Bureau courts were to take jurisdiction of civil and criminal cases involving those freedmen who were unable to enforce their rights in state courts, unless federal courts were available. ${ }^{25}$ The Freedmen's Bureau was particularly important in helping the freedmen enforce their

70. Kaczorowski, Revolutionary Constitutionalism, supra note 9, at 874-77, 897-98; Kaczorowski, To Begin the Nation Anew, supra note 9, at 50-51.

71. See, e.g., General Orders No. 3, Jan. 12, 1866, Adjutant General's Office, reprinted in ThE Political History of The United States of America During the Period of ReconstrucTION 122-23 (E. McPherson ed. 1875); General Orders No. 7, Mar. 4, 1866, Hdqts., Dep't of South Carolina, reprinted in Cong. Globe, 39th Cong., 1st Sess. 1834 (1866).

72. J. Sefton, The United States ARmy and Reconstruction 70-72, 90 (1967); J. Williamson, After Slavery: The Negro in South Carolina During Reconstruction 77 (1965).

73. General Orders No. 3, supra note 71 , at 123.

74. Id.

75. See, e.g., General Orders No. 7, supra note 71. 
contracts, since local law enforcement agencies and courts usually refused to enforce the freedmen's rights. ${ }^{76}$

Following the military's example, the framers provided for the enforcement of civil rights directly in the federal courts. They sought to void racially discriminatory state laws which infringed civil rights secured by the Constitution, eliminate racial and political prejudice in the administration of civil and criminal justice in the State courts, and provide an alternative system of civil and criminal justice when individuals could not enforce or were denied their civil rights in the state courts. ${ }^{77}$

The means the framers adopted to achieve these objectives reflected their understanding of the legal rules which shaped the remedies they could provide. Congressmen James Wilson, the floor manager of the Civil Rights Act in the House of Representatives, summarized these doctrinal and factual considerations in explaining the statute's provisions for direct enforcement of civil rights in the federal courts. After quoting -Justice Story's statement in Prigg v. Pennsylvania that the national government could compel enforcement of federal duties and constitutional rights only through the executive department and courts of the United States, ${ }^{78}$ Wilson proclaimed that since United States citizens, as such, possessed the rights to life, liberty, and property, and rights incident thereto including "the great fundamental rights embraced in the Bill of Rights," they were entitled to a remedy when these rights were violated..$^{78}$ Referring to Prigg and other decisions, he said: "That is the doctrine of the law as laid down by the courts. There can be no dispute about this. The possession of the rights by the citizen raises by implication the power in Congress to provide appropriate means for their protection; in other words, to supply the needed remedy." ${ }^{\mathrm{B} 0} \mathrm{He}$ asked if a state deprived the citizen of these rights by preventing him from enforcing these rights through legal process,

have we no power to make him secure in his priceless possessions? When such a case is presented can we not provide a remedy? Who will doubt it? Must we wait for the perpetration of the wrong before acting? Who will affirm this? The power is with us to provide the necessary protective remedies. ${ }^{81}$

76. D. Nieman, To Set the Law in Motion: The Freedmen's Bureau and the Legal RightS OF BlackS 179-89 (1979).

77. The framers thus provided in law the kinds of relief the military offered under emergency conditions. The framers stated that they were doing only what the military had been authorized to do under President Johnson to fend off the objections of Democrats. See ConG. GLobE, supra note 1, at 1759 (Sen. Trumbull); id. at 1119 (Rep. Wilson); id. at 1124 (Rep. Cook); id. at 1153 (Rep. Thayer); id. at 1158, 1160 (Rep. Windom); id. at 1263 (Rep. Broomall); id. at 1833-35 (Rep. Lawrence).

78. See supra note 15 and accompanying text.

79. Conci. Globe, supra note 1, at 1294 (Rep. Wilson).

80. Id. (emphasis added).

81. Id. 
Then, in an explicit rejection of the kind of enforcement scheme that the doctrine of state action would have required under existing law, Wilson asked, if Congress did not have the authority to provide the remedies, then

from whom shall they come? From the source interfering with the right? Not at all. They must be provided by the Government of the United States, whose duty is to protect the citizen in return for the allegiance he owes to the Government. ${ }^{82}$

These comments express an intention to enforce absolute rights of United States citizenship in national institutions independent of the states, not a right to equal rights under state law. They show that the framers believed not only that Congress was restricted to enforcing federal rights exclusively through the executive and judicial branches of the United States government but that it also was restricted to enforcing only rights secured by the Constitution and laws of the United States. That the framers provided for the enforcement of civil rights directly in the federal courts shows that they believed they were enforcing plenary authority to protect constitutionally secured rights of United States citizenship.

It is not surprising that the framers did not question Congress' authority to redress wrongs committed by private individuals who violated citizens' civil rights. As Senator Trumbull declared: "The right to punish persons who violate the laws of the United States cannot be questioned." He expressed the belief that prosecuting community leaders was the most effective way of stopping the racially and politically motivated civil rights violations that were endemic to the South during this period:

- When it comes to be understood in all parts of the United States that any person who shall deprive another of any right or subject him to any punishment in consequence of his color or race will expose himself to fine and imprisonment, I think such acts will soon cease.

I think it will only be necessary to go into the late slaveholding states and subject to fine and imprisonment one or two in a state, and the most prominent ones I should hope at that, to break up this whole business. ${ }^{84}$

Moreover, the framers' knowledge of federal law and legal process oriented them to provide for the judicial enforcement of the civil rights secured through section one in actions primarily brought by and against private individuals in the federal courts. ${ }^{85}$ Civil suits against state and local officials were rare in the nineteenth century. The model of litigation

82. Id. (emphasis added); see also id. at 1118 (Rep. Wilson).

83. Id. at 475 (Sen. Trumbull).

84. Id.

85. Id. at 605 (Sen. Trumbull). 
was civil suits brought by and against private parties. Thus, Congressman Thayer declared that the statute provides for the enforcement of the fundamental rights of citizens

through the quiet, dignified, firm, and constitutional forms of judicial procedure. The bill seeks to enforce these rights in the same manner and with the same sanctions under and by which other laws of the United States are enforced. It imposes duties upon the judicial tribunals of the country which require the enforcement of these rights. It provides for the administration of laws for the enforcement of these rights. ${ }^{86}$

Consequently, section two of the Civil Rights Act criminalized violations of civil rights committed under color of law or custom. Section three conferred jurisdiction on the federal courts to enforce the rights enumerated in section one.

Criminalizing civil rights violations committed under color of law or custom was an ingenious way of circumventing four substantial obstacles to civil rights enforcement in the federal courts. The first obstacle was how to impose criminal sanctions for violations of civil rights without supplanting state and local governments in their ordinary police functions. The framers expressly intended to preserve state jurisdiction over ordinary crimes by limiting federal criminal violations of civil rights to those committed under color of law or custom. ${ }^{87}$

A second obstacle to effective civil rights enforcement was the cost involved in enforcing civil rights through civil litigation in the federal courts. This cost would have rendered federal civil remedies a virtual nullity for those impoverished freedmen who needed them the most. The framers believed that penal remedies were more effective than civil remedies because the government would bear the cost of this protection, and because the deterrent effect of criminal penalties was greater than that of civil damages. The framers expressed these views in rejecting an amendment to the Civil Rights Bill that would have substituted civil remedies for the penal sanctions of section two. ${ }^{88}$ Congressman Wilson asserted that civil remedies would require the victim to "press his own way through the courts and pay the bills attendant thereon. This may do for the rich," Wilson observed, "but to the poor, who need protection, it is a mockery."89 Civil damages were inadequate protection for another reason, $\mathrm{W}^{7}$ ilson declared: "The citizen can only receive that protection in the form of a few dollars

86. Id. at 1153 (Rep. Thayer). See also id. at 479 (Sen. Saulsbury); id. at 598-99 (Sen. Davis); id. at 601 (Sen. Hendricks); id. at 1271 (Rep. Kerr); id. at 1292 (Rep. Bingham).

87. Id. at 1120 (Rep. Wilson); id. at 1294 (Rep. Shellabarger); id. at app. 158 (Reps. Delano, Wilson, and Niblack); id. at 1758 (Sen. Trumbull).

88. Id. at 1266 (Rep. Bingham).

89. Id. at 1295 (Rep. Wilson). 
... if he shall be so fortunate as to recover against a solvent wrongdoer." more appropriate remedy for and protection from the violation of civil rights: "This is called protection. This is what we are asked to do in the way of enforcing the bill of rights. Dollars are weighed against the right of life, liberty, and property. Sir, I cannot see the justice of that doctrine." States to provide proper protection, and to pay the costs attendant on it."

The third obstacle to effective civil rights enforcement was the rules of sovereign immunity which prevented federal courts from reaching a significant source of the violations-state officers, particularly state judges who failed to dispense justice impartially because they were immune from civil suit. Thus, Congressman Lawrence observed that one way "of meeting any and every willful deprivation of these rights . . . [is] by action for damages at common law in the courts, which, however, will not lie against judicial officers." ${ }^{\text {"93 }}$ Criminal penalties avoided the rules of sovereign immunity and enabled federal courts to make state officers account for their wrongs when civil suits could not.

Opponents used state sovereign immunity and dual sovereignty to decry the framers' intention to punish state officials for enforcing state laws. Congress was condemned for unconstitutionally interfering with and destroying the independence of state governments. ${ }^{94}$ In defense, Senator Trumbull admonished the opposition:

The right to punish persons who violate the laws of the United States cannot be questioned, and the fact that in doing so they acted under color of law or usage in any locality affords no protection, because by the Constitution that instrument and the laws passed in pursuance thereof are the supreme law of the land, and every judge, not only of the United States, but of every State court, is bound thereby. ${ }^{80}$

Senator Trumbull's statement suggests the fourth obstacle to effective civil rights enforcement: the lack of congressional authority to compel state officials to perform federal duties. Although state officers were bound by the Constitution and laws of the United States, Congress could not re-

90. Id.

91. Id.

92. Id. However, Congress later provided civil damages for violations of civil rights committed under color of law, a provision patterned on section two. See Ku Klux Klan Act of 1871, ch. 22, 17 Stat. $13, \S 1$ (1871), 42 U.S.C. $\$ 1983$ (1982).

93. Cong. Globe, supra note 1, at 1836 (Rep. Lawrence).

94. See id. at 506 (Sen. Johnson); id. at 603 (Sen. Cowan); id. at 1120-22 (Rep. Rogers); id. at 1154 (Rep. Eldridge); id. at 1265-66 (Rep. Davis); id. at 1267 (Rep. Raymond); id. at 1270-71 (Rep. Kerr); id. at 1291 (Rep. Bingham); id. at 12956 (Rep. Latham); id. at 1100 (President Johnson's veto message); id. at app. 182, 183 (Sen. Davis).

95. Id. at 1759 (Sen. Trumbull). 
quire state officers to enforce rights secured by the Constitution and laws of the United States. Thus, Congressman Latham objected to section two because "it has been long determined that United States laws must be executed by United States officers." ${ }^{\text {"96 }}$ The only remedy for the state's violation of constitutional rights was appeal to the United States Supreme Court. By criminalizing civil rights violations committed under color of law, Congress intended to circumvent the rules of sovereign immunity and the doctrine of dual sovereignty, and to compel state officers to perform the federal duty of enforcing the civil rights of American citizens.97

The framers clearly intended to impose section two criminal sanctions on state officials who infringed citizens" rights. However, the "under color of law or custom" limitation on federal criminal violations of civil rights was not the equivalent of state action. Inasmuch as the framers understood that private individuals in the South were violating civil rights under color of law and customs, it is illogical to argue that Congress sought to limit these sanctions to state officers. Moreover, the framers expressly stated that they intended to punish anyone who violated the statute, not just state officials. ${ }^{98}$ The framers undoubtedly sought to protect blacks from the abuses of their former masters and employers. In the debates, the framers identified these abuses as holdovers from the customary practices in slavery. When they inserted "custom," they meant custom. The framers also must have intended to protect the freedmen from private individuals who violated their civil rights under color of law.99 Whenever a landowner bought the services of a freedman convicted of vagrancy under discriminatory vagrancy statutes, he acted under color of law. Every time a landowner refused to sell or rent property to a black in a state in which blacks were denied this right by law, the landowner deprived a citizen of his right to property under color of law. Whenever an employer enforced oppressive and discriminatory terms of an employment contract in the courts, he acted under color of law. Whenever a former master apprenticed his former slaves in apprenticeship contracts under state laws that withheld from black apprentices the benefits provided white apprentices,

96. Id. at 1296; see also id. at 1292 (Rep. Bingham).

97. Id. at 475-76, 1758-59 (Sen. Trumbull); id. at 1119 (Reps. Wilson and Loan); id. at 1836, 1837 (Rep. Lawrence). In considering the constitutionality of section two in 1879, the United States Supreme Court acknowledged that Congress could not compel a state officer to perform a federal duty. Ex parte Virginia, 100 U.S. 339, 347 (1879). However, it interpreted the Fourteenth Amendment as conferring on Congress the authority to punish state officers "for neglect cr refusal to perform the duty required by the act of Congress." Id. Nonetheless, in upholding the indictment of a state judge for excluding blacks from the grand jury, the Court was careful to insist.that the unlawful act was a ministerial and not an "official" act. Id. at 348 . In their dissent, Justices Field and Clifford challenged this reasoning. Id. at 353-60.

98. ConG. Globe, supra note 1, at 601 (Sen. Hendricks); id. at 1124 (Rep. Cook); id. at 1153 (Rep. Thayer); id. at 1156 (Rep. Eldridge); id. at 1156 (Rep. Thornton); id. at 1159 (Rep. Windam); id. at 1295 (Rep. Wilson); id. at 1833 (Rep. Lawrence); id. at App. 183 (Sen. Davis); Kaczorowski, To Begin the Nation Anew, supra note 9, at 63-64.

99. See supra note 59 and accompanying text. 
the master acted under color of law. Whenever individuals brought vexatious suits or swore out false criminal complaints against white Unionists and federal officials they acted under color of law. The color of law and custom limitation on section two's criminal sanctions does not reflect a state action conception in the minds of the framers. Given the interconnection between law and custom that deprived blacks and whites of their civil rights, it is illogical to argue that the framers distinguished between state action and private action and intended to protect civil rights only against the former. It is more faithful to the expressed intentions of the framers to interpret "under color of law and custom" as their ingenious device to punish criminal civil rights violations committed by private individuals and public officials in a way that preserved state jurisdiction over ordinary crimes and that circumvented obstacles to federal civil rights enforcement presented by dual sovereignty and sovereign immunity. ${ }^{100}$

Moreover, the framers did not consider it unusual to enforce federal authority against private individuals; that was the usual way of enforcing federal law. Rather, what they regarded as extraordinary was requiring state officers, under threat of criminal prosecution, to enforce federal law, especially when it conflicted with state law. ${ }^{101}$ Yet, they imposed criminal sanctions and intended those sanctions to be applied against state judges who disregarded the provisions of the Civil Rights Act. ${ }^{102}$ Therefore, section two represents an expansion of federal sanctions for civil rights violations by adding state officials to private individuals as potential defendants. Next to providing a federal forum to adjudicate cases involving civil rights directly, this was the most effective way the framers believed they could nullify discriminatory state statutes and legal processes. They took this action even though it represented a remarkable breach of federal comity because they felt so strongly about enforcing the civil rights of United States citizens.

The jurisdictional provisions of section three of the Civil Rights Act went beyond the criminal sanctions provided in section two. Section three conferred exclusive jurisdiction on the federal district courts over "all crimes and offences committed against" its provisions. Significantly, it also conferred concurrent jurisdiction on federal district and circuit courts over "all causes, civil and criminal, affecting persons who are denied or cannot enforce in the courts or judicial tribunals of the State or locality where they may be any of the rights secured to them by the first section [of the statute]." Such persons could bring their causes into federal court either by originating the action in the federal court or by removal from a state

100. See, e.g., Cong. Globe, supra note 1, at 475, 1759 (Sen. Trumbull); id. at 1836 (Rep. Lawrence).

101. Id. at 1758-59 (Sen. Trumbull).

102. Id. at 500 (Sens. Cowan and Trumbull); id. at 1154 (Rep. Eldridge); id. at 1265-66 (Rep. Davis). 
court. This provision manifests the framers' intention to confer on the courts of the United States primary civil and criminal jurisdiction over civil rights in order to enforce these rights in the circumstances that confronted Congress in 1866. The framers authorized the federal courts to replace state courts, and to try civil and criminal cases that were within the jurisdiction of the state courts and which state courts otherwise would have tried, whenever individuals could not enforce their rights in or were denied their rights by state courts. This is the import of Congressman Wilson's admonition that, since the states were not protecting the personal rights of American citizens, "we must do our duty by supplying the protection which the states deny." 103

In addition to Southern blacks and Union loyalists, the framers responded to the plight of federal civil and military officials assisting the freedmen and enforcing federal authority. Section three conferred on civil and military officers of the United States a right to remove any civil suit or criminal prosecution commenced against them in any state court for actions taken to enforce the Civil Rights Act and the Freedmen's Bureau Act.

Section three established a federal system of civil and criminal justice as an alternative to those of the states when Americans could not enforce or were denied their civil rights in state courts. Opponents objected that this provision would transfer from the state courts to the courts of the United States all civil suits between citizens of a state concerning private transactions and private wrongs. ${ }^{104}$ Indeed, they warned that "every little petty case of a civil character in which from ten cents to thousands of dollars are involved" would be absorbed by the federal courts. ${ }^{103}$ Opponents also emphasized that section three provided that crimes such as "murder shall be taken from the jurisdiction and control of the State courts, and that the district and circuit courts of the United States shall have exclusive jurisdiction of it." 108 They predicted "that the whole criminal code of the State, if the Federal courts can have the power of administering it, will be administered by the Federal courts and not the State courts." ${ }^{\text {"107 }}$ These

103. Id. at 1118 (Rep. Wilson); see also id. at 602-03 (Sen. Lane).

104. Id. at 598-99 (Sen. Davis).

105. Id. at 479 (Sen. Saulsbury).

106. Id. Justice Field, with Justice Clifford concurring, declared that federal courts cannot exercise jurisdiction over criminal prosecutions for murder commenced in the courts of the state because such prosecutions did not arise under the Constitution and laws of the United Sitates. Rather, such criminal offencts were against the laws of the states whose courts have exclusive jurisdiction over them. Virginia v. Rives, 100 U.S. 313, 336 (1879) (Field, J. concurring). However, the Supreme Court permitted the removal of state criminal prosecutions when state statutes violated a citizens' right to the equal protection of the laws in state courts. Strauder v. West Virginia, 100 U.S. 303, 312 (1879). Removal was authorized only if the right that was denied or could not be enforced was one secured by the Constitution and laws of the United States. Dubuclet v. Louisiana, 103 U.S. 550, $552-53(1880)$

107. Cong. Globe, 39th Cong., 1st Sess. 479 (Sen. Saulsbury); see also id. at 601 (Sen. Hendricks); id. at 1271 (Rep. Kerr); id. at 1291-92 (Rep. Bingham). 
enforcement provisions make clear that opponents were not exaggerating for political effect when they objected that, if Congress possessed the constitutional authority to enact the Civil Rights Act, it could supplant state civil and criminal codes. ${ }^{108}$

Proponents, of course, did not wish to supplant state civil and criminal administration of justice any more than was necessary to meet the emergency that confronted them. ${ }^{109}$ However, they felt a great need to defend the revolutionary powers they were extending to the federal courts and executive officers. They justified this legislation by insisting that they were merely providing through civil and criminal process the relief that the Union army was offering under military powers. ${ }^{110}$ The need they felt to justify this enormous intrusion on state jurisdiction also explains the emphasis they placed on the enactment of racially discriminatory state laws and law enforcement as conclusive evidence of the need for federal civil rights protection. ${ }^{111}$

There were seven additional enforcement provisions, most of which were taken from the Fugitive Slave Act of 1850, which granted broad powers to the executive and judicial branches of the national government. Sections four and five required United States attorneys, marshals, commissioners, and any other officers appointed by the President to arrest and prosecute all persons who violated the statute. Section six provided criminal penalties against anyone who interfered with the enforcement of the Givil Rights Act. Section nine authorized the President "to employ such part of the land or naval forces of the United States or of the militia, as shall be necessary to prevent the violation and enforce the due execution of this act." Section ten authorized final appeal to the United States Supreme Court of all questions of law arising in any cause under the act.

The enforcement provisions demonstrate the framers' understanding that they were enforcing absolute rights secured by the United States Con-

108. See Kaczorowski, Revolutionary Constitutionalism, supra note 9, at 903-09. Section three also authorizes the federal courts, whenever federal statutes are inadequate, "to furnish suitable remedies and punish offences against the law," and to extend "the common law, as modified and changed by the constitution and statutes of the State wherein the court . . . is held, so far as the same is not inconsistent with the constitution and laws of the United States." This was interpreted in the debates as authorizing a federal common law. Cong. Globe, supra note 1, at 1271 (Rep. Latham). This seems to be the clear meaning, especially in light of the development of federal common law that was occuring in other areas of law. See T. Freyer, Harmony \& Dissonance: The Swift and Erie Cases in American Federalism (1981).

109. Cong. Globe, supra note 1, at 1837 (Rep. Lawrence).

110. Id. at 603 (Sen. Wilson); id. at 1119 (Rep. Wilson); id. at 1123-24 (Rep. Cook); id. at 1153 (Rep. Thayer); id. at 1158, 1160 (Rep. Windom); id. at 1263 (Rep. Broomall); id. at 1759 (Sen. Trumbull); id. at 1833-35 (Rep. Lawrence).

111. Id. at 602-03 (Sen. Lane); id. at 603 (Sen. Wilson); id. at 605, 1759 (Sen. Trumbull); id. at 1117-18, 1294 (Rep. Wilson); id. at 1124-25 (Rep. Cook); id. at 1155 (Rep. Thayer); id. at 1263-65 (Rep. Broomall); id. at 1266-67 (Rep. Raymond). Although the framers contemplated federal courts exercising original and removal jurisdiction over civil rights cases when state statutes and judicial process did not permit persons to enforce their rights, with the grant of federal question jurisdiction in 1875 , federal courts would have sufficient jurisdiction to enforce section one rights even if section three jurisdiction was interpreted as requiring discriminatory state action. 
stitution and not simply an equality in state-conferred rights. This conclusion is further demonstrated by the statute's enforcement provisions taken from the Fugitive Slave Act of 1850, which also was enacted to enforce constitutionally protected "rights of Americans, the rights of slaveholders in their slaves." 112 The jurisdiction Congress conferred on the federal courts to enforce civil rights directly evinces the framers' intention to apply its authority beyond the removal of legal disabilities. Congress could confer this jurisdiction on the federal courts to enforce civil rights only if the framers believed that Congress had authority to enforce the rights themselves. If the statute had only removed legal disabilities in state law by prohibiting racially discriminatory state laws regarding state-conferred rights or by conferring a right to racially impartial state laws relating to state-conferred rights, Congress could not have conferred on United States courts section three jurisdiction to try civil actions between private parties and criminal cases. ${ }^{113}$ This conclusion is inescapable in light of prevailing constitutional doctrine of the framers' era which held that the remedy was coextensive with the right conferred. ${ }^{114}$ Moreover, a statute limited to removing the legal disabilities of blacks would not have afforded protection to the civil rights of whites, and the framers clearly expressed their understanding of the Civil Rights Act as giving whites the same protection as blacks. ${ }^{115}$ It is simply illogical to interpret section one as merely removing legal disabilities when section two criminalizes certain violations of section one rights, section three confers on federal courts primary civil and criminal jurisdiction over cases involving these rights, and other provisions called on the executive officers and the armed forces of the United States

112. Id. at 476, 605, 606, 1757 (Sen. Trumbull); id. at 500 (Sen. Stewart); id. at 601 (Sen. Hendricks); id. at 602 (Sen. Lane); id. at 603-04 (Sen. Cowan); id. at 605, 606 (Sens. Norton and Trumbull); id. at 1118-19, 1295 (Rep. Wilson); id. at 158-59 (Rep. Windom); id. at 1296 (Rep. Latham).

113. This conclusion follows from the prevailing doctrine of dual sovereignty. The Court held that rights granted and secured by the states and duties imposed by state law could not be enforced directly in the federal courts, either by civil action or by criminal sanctions. Congress could enforce directly only rights secured and duties imposed by the Constitution and laws of the United States. Ex parte Siebold, 100 U.S. 371, 387-89 (1879); Ex parte Clarke, 100 U.S. 399, 409-11 (1879); Ex parte Yarbrough, 110 U.S. 651, 658-65 (1884); Carter v. Greenhow, 114 U.S. 317, 322-23 (1884); United States v. Anthony, 24 F. Cas. 829 (C.C.D.N.Y. 1873) (No. 14,459); Cully v. Baltimore \& O.R. Co., 6 F. Cas. 946 (D.C.D. Md. 1876) (No. 3,466); In re Mahon, 34 F. 528 (1888).

114. See Slaughter-House Cases, 83 U.S. (13 Wall.) 36, 76-81 (1873); United States v. Cruikshank, 92 U.S. 542, 552-57 (1875); Civil Rights Cases, 109 U.S. 3, 11-15 (1883).

115. Cong. Globe, supra note 1, at 474, 599 (Sen. Trumbull); id. at 1118 (Rep. Wilson). For -additional authority, see Kaczorowski, Revolutionary Constitutionalism, supra note 9, at $897 \mathrm{n} .153$. The framers' intention to enforce the civil rights of Southern white unionists reflects details of the historical context of the statute peculiar to the era of the Civil War and reconstruction. Although the framers understood the need and intended to protect blacks, as blacks, from racial discrimination, they did not intend to protect whites, as whites. Rather, they understood that the need to protect whites arose from their association with the Union cause and loyalty to the United States government to political loyalists or as federal officials. Because these conditions no longer exist, it is difficult to imagine the Civil Rights Act being applied to protect whites today in any way other than as victims of racial discrimination as the Court has done in St. Francis College v. Al-Khazraji, 107 S. Ct. 2022 (1987) and Shaare Tefila Congregation v. Cobb, 107 S. Ct. 2019 (1987). 
to enforce the Civil Rights Act. The historical context of this legislation, the legal theories on which it was grounded, and its very provisions conclusively demonstrate that Congress intended to enforce civil rights whether the violation was the act of a private individual, a state official or a state statute. The ambiguity in the scope of the Givil Rights Act is the product of subsequent misintepretation of the statute's legislative history based on modern doctrines that have no applicability in determining the framers' intent. ${ }^{118}$

\section{How We Got Here From There: The Supreme Court's (Mis)INTERPRETATION OF THE Givil Rights ACT}

I have shown elsewhere that federal judges and legal officers who were given the responsibility of implementing the Civil Rights Act of 1866 on its enactment into law, as well as state appellate judges, uniformly interpreted and enforced it in a manner that reflected the interpretation argued in this Comment. ${ }^{117}$ Space permits us only a very brief look at the way in which the United States Supreme Court essentially rewrote the Act over the first half-century after its enactment. We can trace three key threads through this period: the reading of a state action limitation into the Civil Rights Act, the transformation of the doctrine of dual sovereignty, and the abandonment of the Hamiltonian theory of congressional power to enforce constitutional rights.

The Supreme Court first considered the constitutionality of the Civil Rights Acts in 1872. ${ }^{118}$ The issue in the case was whether black victims of crimes committed by whites were persons affected by the prosecution for purposes of federal court jurisdiction under section three. Although the Court held that they were not because the only persons so affected are the defendant and the state, and thus eliminated federal jurisdiction to try white defendants for crimes against blacks, it upheld the constitutionality of the Civil Rights Act and interpreted it broadly in other respects. The Supreme Court appealed to the legislative history of the statute and declared that it was "well known" that the Civil Rights Act was intended to protect blacks from "prejudices [that] existed against the colored race, which naturally affected the administration of justice in the State courts,

116. In his dissent in Jones v. Alfred H. Mayer Co., 392 U.S. 409 (1968), Justice Harlan insisted that the quotations from the legislative debates used by the majority as evidence of the framers' intent to protect civil rights from private discrimination "are by no means contrary to a "state action" view of the civil rights bill." Id. at 471 . He, of course, was insisting upon a state action interpretation of the statute. Justice Harlan's view is untenable in light of the nature of the civil rights violations Congress was attempting to remedy, the legal doctrines that shaped their understanding of the remedies Congress could provide to counteract these violations, and the enforcement provisions they actually adopted.

117. R. KaCzorowski, supra note 6, at 1-12; Kaczorowski, Revolutionary Constitutionalism, supra note 9, at 900-03, 907-09; Kaczorowski, To Begin the Nation Anew, supra note 9, at 56-62.

118. Blyew v. United States, 80 U.S. (13 Wall.) 581 (1872). 
and operated harshly when one of that race was a party accused."119 The Court also interpreted the statute as conferring the rights enumerated in section one, not simply as removing legal disabilities, but as securing the civil rights of whites as well as blacks when it declared that the Givil Rights Act "extends to both races the same rights, and the same means of vindicating them."120

The Slaughter-House Cases ${ }^{121}$ and United States v. Cruikshank, ${ }^{122}$ however, began unraveling this interpretation of the Civil Rights Act. In his majority opinion in the Slaughter-House Cases, Justice Miller rejected Congress' theory of United States citizenship and congressionallyenforceable rights and declared that the natural rights to life, liberty and property and the civil rights incident thereto were rights of state citizenship and therefore enforceable exclusively by the states. ${ }^{123}$ The rights secured to United States citizens by the Fourteenth Amendment were relatively minimal rights such as the right to protection while in a foreign country, the right to use the navigable waterways of the United States, the right to interstate travel, and the right to petition Congress for the redress of grievances. ${ }^{124}$ The Court interpreted the Thirteenth Amendment as a guarantee against the reinstitution of slavery. ${ }^{125}$

In Cruikshank, decided three years later, the Court affirmed this interpretation of citizenship and held that the authority and duty to protect the inalienable rights of citizenship were exclusively within state sovereignty. ${ }^{128}$ The Court expressly excluded any consideration of the Civil Rights Act of 1866 and discussed national civil rights enforcement authority as if it were wholly contained in the Fourteenth Amendment. The Court held that, as the Fourteenth Amendment prohibits the states from denying the equal protection of the laws, "[ $t$ ]he only obligation resting upon the United States is to see that the States do not deny the right. This

119. Id. at 593 .

120. Id. Federal judges, United States attorneys general and United States attorneys, along with Congress, consistently interpreted the scope of federal authority to enforce civil rights under the Thirteenth and Fourteenth Amendments and the Civil Rights Act of 1866, the Enforcement Act of 1870 and the Klu Klux Klan Act of 1871 as plenary authority to redress civil rights violations regardless of the source of the infringement. See R. KAczorowski, supra note 6. The federal courts and the Department of Justice virtually administered criminal justice in areas of the South where the Klan and similar organizations overwhelmed local law enforcement officers and institutions. Federal judges without exception upheld the constitutionality of those civil rights statutes and enforced them to prose.cute private individuals as well as state officials. Federal judges did not acknowledge a state action limitation on national civil rights enforcement authority until the Supreme Court's decision in the Slaughter-House Cases.

121. 83 U.S. (16 Wall.) 36 (1872).

122. 92 U.S. (2 Otto) 553 (1875).

123. 83 U.S. at $75-78$.

124. Id. at 79-80.

125. Id. at $69-70$.

126. United States v. Cruikshank, 92 U.S. (2 Otto) 553 (1875). 
the amendment guarantees, but no more. The power of the national government is limited to the enforcement of this guarantee."127

The Court then proceeded, in Virginia v. Rives, to graft its state action interpretation of the Fourteenth Amendment onto the Civil Rights Act of 1866. Acknowledging that the statute was enacted prior to the certification of the amendment, the Court nonetheless declared that it was re-enacted "upon the first section of that amendment." ${ }^{\text {"128 }}$ Overlooking or ignoring its earlier comment that it was well known that Congress intended section three to protect blacks from racial prejudice in the administration of justice, ${ }^{129}$ the Court stated that the removal provisions of section three were limited, as was the Fourteenth Amendment, to racially discriminatory state action. Furthermore, sovereign immunity doctrine prompted the Court to hold that racially discriminatory action by a state officer was not the act of the state if the officer was acting beyond his power under state law. ${ }^{130}$ Therefore, removal was available only before trial, and only when the state constitution or law was racially discriminatory. The Court declared that the exclusive remedy for the violations of civil rights committed by state judges and executive officers was review and correction by the Supreme Court. ${ }^{131}$ Only in 1907 did the Court change the doctrine of state sovereign immunity in a way that permitted suits against state officers under a theory of state action. ${ }^{\mathbf{1 3 2}}$

The companion case of Strauder $v$. West Virginia, which presented a racially discriminatory law, created a contradiction in the Court's doctrine. The Court interpreted section three of the Civil Rights Act to allow removal of a case to federal court where state law excluded blacks from serving on grand and petit juries. The Act granted the right to remove whenever "any rights secured to [persons] by any law providing for the "equal civil rights of citizens of the United States" was denied by state law. ${ }^{133}$ Accordingly, the Court had to hold that the state law interfered with rights pertaining to federal citizenship. In contrast to its holdings in Slaughter-House and Cruikshank that the Fourteenth Amendment secured a right to racially impartial state law, the Court now held that the amendment implied "the existence of rights and immunities, prominent among which is an immunity from inequality of legal protection, either

127. Id. at 555 .

128. Virginia v. Rives, 100 U.S. 313,333 (1879).

129. See supra note 119 and accompanying text.

130. Rives, 100 U.S. at 334.

131. Id. at 321-22; Neal v. Delaware, 103 U.S. 370, 387 (1880).

132. Ex Parte Young, 209 U.S. 123, 158-60 (1907).

133. Id. at 311 . In other cases the Court held that federal courts did not have jurisdiction to try cases involving rights that were secured by the states. Dubuclet v. Louisiana, 103 U.S. 550, 552-53 (1880) (right to vote and hold state office); Carter v. Greenhow, 114 U.S. 317, 322 (1884) (right to pay state taxes with interest coupons granted by the state). But see United States v. Buntin, 10 F. 730 (C.C.S.D. Ohio 1882) (federal jurisdiction under section two of the Civil Rights Act of 1866 to punish public school teacher for racial discrimination under state law). 
for life, liberty, or property." The Civil Rights Act, the Court held, "partially enumerat[es] the rights and immunities intended to be guaranteed by the Constitution."

The Court resolved this contradiction in the Civil Rights Cases in 1883. ${ }^{134}$ It interpreted the Fourteenth Amendment as "prohibitory in its character, and prohibitory upon the States." ${ }^{\prime 35}$ Moreover, the amendment "invests Congress with power to enforce it by appropriate legislation," the Court declared, and then asked, "To enforce what?" It answered: "To enforce the prohibition." ${ }^{\text {"138 }}$ The Court elaborated:

Positive rights and privileges are undoubtedly secured by the Fourteenth Amendment, but they are secured by way of prohibition against State laws and State proceedings affecting those rights and privileges, and by power given to Congress to legislate for the purpose of carrying such prohibition into effect: and such legislation must necessarily be predicated upon such supposed State laws or State proceedings, and be directed to the correction of their operation and effect. ${ }^{137}$

The Court identified as the positive rights the amendment was intended to secure "the rights to life, liberty and property (which includes all civil rights which men have)."138 Although the Court declared that these natural rights were secured by the Constitution, it nevertheless insisted that this constitutional guarantee did not delegate to Congress the power to legislate generally regarding them, and therefore to enforce them against private individuals.

The Court thus abandoned the Hamiltonian theory of constitutional interpretation and transformed the established doctrine of dual sovereignty exemplified by such cases as McCulloch $v$. Maryland and Prigg v. Pennsylvania. Instead of interpreting the negative prohibitions of the Fourteenth Amendment as constitutional guarantees of fundamental rights that delegated to Congress plenary authority to enforce civil rights, it allowed Congress only to enforce the prohibitions by intervening when state action violated them. The Court's explanation echoed the Congressional Democrat's opposition to the Civil Rights Act of 1866: Plenary civil rights authority would enable Congress "to establish a code of municipal law regulative of all private rights between man and man in society. It would be to make Congress take the place of the State legislatures and to supercede them." 139 The Court was unwilling to concede this power to Congress.

134. Civil Rights Cases, 109 U.S. 3 (1883).

135. Id. at 10.

136. Id. at 11 .

137. Id. at 11-12.

138. Id. at 13.

139. Id. at 13. See supra notes 104-108 and accompanying text for the views of congressional Democrats. 
Nonetheless, the Court interpreted the Thirteenth Amendment to give Congress this authority. The Thirteenth Amendment not only abolished slavery; it also "established universal freedom."140 Because the amendment "is not a mere prohibition of State laws," it delegated to Congress authority to enact remedial legislation that was "primary and direct in its character," "operating upon the acts of individuals, whether sanctioned by State law or not." 141 The Court interpreted the Civil Rights Act as intended "to secure to all citizens of every race and color, and without regard to previous servitude, those fundamental rights which are the essence of civil freedom."142 Nevertheless, the Court repeated its view that the statute was re-enacted under the Fourteenth Amendment and concluded that "This law is clearly corrective in its character, intended to counteract and furnish redress against State laws and proceedings and customs having the force of law, which sanction the wrongful acts specified."143

Having interpreted one constitutional amendment as limiting Congress to reaching state action and one as not having such a limitation, the Court limited the Civil Rights Act's coverage to state action. It reasoned that Congress re-enacted the statute in 1870 under the Fourteenth Amendment, and it read back into Congress the Court's state action interpretation of the Fourteenth Amendment. The Court ignored the fact that the legislation that re-enacted the Civil Rights Act contained provisions enforcing civil rights against private individuals, as did the Ku Klux Klan Act of $1871 .{ }^{144}$ These statutes show that Congress clearly did not legislate in 1870 and 1871 within a state action interpretation of the Fourteenth Amendment. Moreover, the Court ignored the intention of the original . framers. Using its method of divining legislative intent, the Court should have found no state action limitations in the intent of the framers because the Court interpreted the Thirteenth Amendment as delegating sufficient authority to secure the absolute rights of free citizens, and it was under the authority of the Thirteenth Amendment as the Court interpreted it that the framers adopted the Civil Rights Act. This was a remarkable piece of judicial legislation in which the Court chose narrower guarantees or rights secured by the Constitution and laws of the United States than were available even under its interpretation of the Constitution. This interpretation of the Thirteenth Amendment permits the Court today to correct this aberrant judicial construction of the Civil Rights Act.

140. Civil Rights Cases, 109 U.S. at 20.

141. Id. at $20,23$.

142. Id. at 22.

143. Id. at 16.

144. 16 Stat. 140 (1870); 17 Stat. 13 (1871). 


\section{Conclusion}

The Supreme Court effectively curtailed civil rights enforcement in the nineteenth century by reading into federal civil rights provisions restricted meanings not intended or even considered by their framers. The Court's interpretation of federal guarantees of civil rights is starkly contrasted with its earlier enforcement of slave owners' property rights in their slaves under the fugitive slave clause. In assessing the scope of protection offered by this constitutional provision, the Supreme Court laid down a rule of constitutional interpretation:

How, then, are we to interpret the language of this clause? The true answer is, in such a manner, as, consistently with the words, shall fully and completely effectuate the whole objects of it. If by one mode of interpretation the right must become shadowy and unsubstantial, and without any remedial power adequate to the end, and by another mode it will attain its just end and secure its manifest purpose, it would seem, upon principles of reasoning, absolutely irresistible, that the latter ought to prevail. No Court of justice can be authorized so to construe any clause of the Constitution as to defeat its obvious ends, when another construction, equally accordant with the words and sense thereof, will enforce and protect them. ${ }^{145}$

The same principles should apply to statutory construction. In this context, the question that the Supreme Court unwittingly raised in Patterson is one that Senator Trumbull and his legislative colleagues thought they had answered in 1866: whether they had "enact[ed] a law as efficient in the interest of freedom, now that freedom prevails throughout the country, as we had in the interest of slavery when it prevailed in a portion of the country."148

145. Prigg v. Pennsylvania, 41 U.S. (16 Pet.) 539, 612 (1842).

146. Cong. Globe, supra note 1 , at 475 (Sen. Trumbull). 
